Journal of

Biomedical Engineering and Research

\title{
Cell-Based Treatment of Ischemic Heart Disease: Rationale for the Use of VEGF-Eluting Adult Progenitor Cells
}

\section{John D. Murray MD, FACS ${ }^{1 *}$, Marie Crandall, MD, MPH, FACS ${ }^{2}$, Edward W. Scott, PhD $^{3}$}

${ }^{1}$ The University of Florida at Jacksonville Division of Plastic Surgery

${ }^{2}$ The University of Florida at Jacksonville, Department of Surgery

${ }^{3}$ The University of Florida at Gainesville, Department of Microbiology and Molecular Genetics

*Corresponding author: John Murray, MD, FACS 653 West 8th Street Faculty Bldg., 3rd floor Jacksonville, FL 32209. 904-2443915, Fax 904-244-3870, Email: john.murray@jax.ufl.edu

Received Date: May 03, 2019 Accepted Date: May 27, 2019 Published Date: May 30, 2019

Citation: John D. Murray MD, FACS (2019) Cell-Based Treatment of Ischemic Heart Disease: Rationale for the Use of VEGFEluting Adult Progenitor Cells. J Biomed Eng 1: 1-7.

\section{Introduction}

Cardiovascular disease (CVD) remains the leading cause of death worldwide, with coronary ischemic heart disease accounting for $80 \%$ of deaths from CVD [1-3]. While heart-healthy lifestyle changes remain essential to reducing one's lifetime risk of CVD, prevention and treatment options have otherwise relied on control of blood pressure and blood sugar and cholesterol levels. Interventional techniques have relied on percutaneous coronary intervention and coronary artery bypass grafting [2]. With the total treatment costs of cardiovascular disease rising and expected to reach \$1.1 trillion in 2035 in the United States alone [4], heart failure is in need of new therapies to prevent, as well as reverse, cardiac arterial pathology and enhance cardiovascular regeneration. Herein is presented a concise review of the utility of vascular endothelial growth factor (VEGF) in angiogenesis and rationale for the use of VEGF-eluting stem cells in the treatment of ischemic disease.

Keywords: Adipose-derived stem cells, adult stem cells, VEGF, heart disease, progenitor cells.

(C)2019 The Authors. Published by the JScholar under the terms of the Creative Commons Attribution License http://creativecommons.org/licenses/ by/3.0/, which permits unrestricted use, provided the original author and source are credited. 


\section{VEGF, Cancer, and VEGF Blockade}

The field of angiogenesis has become a target of focused research for both therapeutic angiogenesis as well as therapeutic anti-angiogenesis. As no metabolically active tissue is but a few hundred micrometers from a capillary, all tissues rely on the continual flow of oxygen and micro-nutrients to survive. The field of angiogenesis in the printed literature may be followed back to the Scottish anatomist and surgeon John Hunter. He was the first to provide scientific insights to the fields of angiogenesis and blood flow in his Treatise in 1794; his remarks generally addressed the importance of balance between vascularity and metabolism [5]. The modern era of basic and clinical research related to angiogenesis was anchored by Dr. Judah Folkman in his landmark paper discussing tumor angiogenesis in 1971 [6]. A direct correlation was then established between tumor vascular density and extent of tumor burden, stage, and prognosis [7]. However, it was not until the next decade that the essential protein needed for angiogenesis was discovered: VEGF. VEGF was discovered by Senger and Dvorak in 1983, though they termed it the "vascular permeability factor." [8] Later that same decade (1989), VEGF was independently identified by Ferrara and Henzel as it was isolated from the conditioned media of bovine pituitary cells [9]. Slightly 30 years past the release of Dr. Folkman's seminal paper, and 25 years past Senger and Dvorak's discovery of VEGF, in 2004 the Food \& Drug Administration approved the first anti-angiogenic medication, bevacizumab (Avastin ${ }^{\circledR}$; Genentech, San Francisco, CA), for human use in the treatment of cancer [10]. Bevacizumab is a monoclonal antibody which prevents VEGF binding, which then prevents growth and maintenance of tumor vessels. This medication has significantly added to our chemotherapeutic armamentarium for the treatment of several cancers.

\section{Role of VEGF in angiogenesis}

As VEGF is instrumental in promoting tumor progression, it is also critical in normal tissue and organ development. The maintenance and production of vessels rely on several growth factors and cytokines; VEGF is one of the most critical and well-studied angiogenic growth factors [11]. VEGF is involved in several angiogenic functions, to include endothelial cell migration, mitogenesis, vascular sprouting, and vascular tube formation $[12,13]$. Several isoforms of VEGF are endogenously active; VEGF factor A (VEGF-A) is the most active isoform and is essential for mammalian development and function $[14,15]$. As the family of VEGF comprise a family of both pro- and anti-angiogenic isoforms and related proteins [14,16-19] the delicate balance between these competing peptides presumably maintains vascular homeostasis in vivo while significant increases in anti-angiogenic VEGF-A isoforms, such as VEGF-A165b, reflect impaired vascularization [18].

\section{VEGF protein therapy}

Cytokine therapies, to include fibroblast growth factor, hepatocyte growth factor, stromal cell-derived factor-1 $\alpha$, and recombinant human VEGF, have shown promise in treating ischemic diseases [20]. Several phase I trials using intracoronary and intravenous infusions of VEGF in patients with the coronary disease showed favorable trends [21-23]. However, clinical trials of VEGF gene therapy as well as trials using high dose VEGF therapy, in patients with coronary artery disease or peripheral artery disease, have not demonstrated statistical clinical benefit [22-27]. In the placebo-controlled double-blinded phase II VIVA trial, VEGF failed to show sustainable improvements over placebo in anginal frequency and treadmill test time at four months [23]. Reasons for such failure may lay in the poor stability and cell permeability of exogenous VEGF. Administered peripherally, VEGF demonstrates a short in vivo half-life of about 30 minutes while hypotensive side effects also limit the utility of the infused recombinant protein to achieve angiogenesis [21,23].

Several manufactured VEGF protein delivery vehicles have been developed to improve both targeting damaged tissues and delivery of VEGF. Examples include scaffolds such as cross-linked heparin, hydrogels to nano- and micro-particles of PLGA and collagen, engineered polymers and microspheres [28-30]. Such vehicles may prolong the half-life of payload growth factors and related cytokines [31].

\section{Cell-based therapies}

Cell-based therapies have shown particular promise in several difficult-to-treat conditions and diseases, including neurological, autoimmune, and gastrointestinal targets [3234]. Similarly, cell-based therapy is a promising and emerging new option for promoting angiogenesis and treating ischemic diseases [35-39]. Cell-based therapeutic approaches have involved several classes of putative stem cells, ranging from bone marrow-derived mononuclear cells, endothelial progenitor cells, mesenchymal stem cells (MSCs), and pluripotent stem 
cells [40]. CD-34 positive bone marrow-derived stem cells, in particular, have been well characterized and have been used clinically to rebuild the hematopoietic system after chemotherapy; such utility in the treatment of ischemic heart disease is promising $[41,42]$.

\section{Mesenchymal stem cell-based therapies}

MSCs exist in several tissues in an undifferentiated state with the ability to self-renew and differentiate along several mesodermal lineages [43-50]. Human MSCs derived from adipose, so-called adipose-derived stem/stromal cells (ASCs), are easily isolated from lipoaspirate and secrete a wide array of proangiogenic cytokines and differentiate into multilineage progenitor cells [16,47,51-53]. Since angiogenesis and organogenesis are normally coupled, it is possible that human adipose-derived progenitor cells (APCs) could modulate levels of vascular endothelial growth factor (VEGF) in a lineage-dependent manner. Animal studies have shown that ASCs have the potential to differentiate in vivo into endothelial cells and cardiomyocytes [54-56]. MSCs have also shown to be immune-evasive and, as such, may be both effective in vivo after autogeneicor allogeneic transplantation [57]. Additionally, culture-expanded MSCs have been shown to decrease inflammation and T-cell proliferative responses because of their reduced expression of surface histocompatibility antigens [58].

While the use and potential benefit of MSCs in cardiovascular disease have been widely published, such benefit seems unlikely solely from the differentiation of these cells to cardiomyocytes. MSC-derived cardiomyocytes have been shown to fail permanent engraftment and become nonviable within a few hours after administration $[59,60]$. However, APCs may elaborate greater quantities of paracrine and autocrine cytokines comparative to MSCs in their undifferentiated state [59-62].Therefore, modification of MSCs to APCs before delivery could promote expression of VEGF-A, favorably augmenting the capacity for cardiac repair.

\section{VEGF-eluting adult progenitor cell therapies}

MSCs differentiate down both mesodermal and endothelial lineages while participating in angiogenesis by secreting angiogenic paracrine factors, including VEGF, basic fibroblast growth factor (bFGF), and platelet-derived growth factor (PDGF) [63-67]. Such the dichotomy is well revealed in an embryologic study of vessel formation. A delicate balance lies between differentiated mesodermal embryonic stem cells and endodermal paracrine signaling. Angioblasts, as derived from the splanchnic mesoderm, give rise to capillaries. The angioblasts assemble themselves into a primitive vascular plexus under the influence of VEGF [68]. VEGF-A binds to Fetal Liver Kinase-1 (FLK-1), which activates several intracellular transduction pathways for vessel formation [68]. It has been shown that in mice lacking FLK-1, the mice develop angioblasts but not vessels; as such, VEGF signaling is critical to the development of vessels [68]. High and low levels of VEGF also lead to differing second messenger expression, determining the development of arteries (high VEGF concentration) and veins (lower VEGF concentration) $[68,69]$.

Proangiogenic signal transduction and feedback loops between developing and renewing stems cells and their cytokines continue beyond the embryonic period and into undifferentiated adult stem cells, [12]. ASCs have been shown to promote angiogenesis by producing VEGF, human growth factor (HGF), and tissue growth factor- $\beta$. VEGF-A has been shown to be a key regulator of perichondrial angiogenesis and osteoblast differentiation at the early stages of bone development $[70,71]$. Additionally, autocrine, or intracellular, VEGF has been shown to play a key role in the differentiation of MSCs, not only by modulating cell surface receptors but by also linking to protein lamin A on the nuclear envelope [72].

Therapeutically, ASCs have been shown to improve blood flow in a mouse model of hindlimb ischemia by secreting growth factors, including VEGF and HGF [73]. Laboratory studies and limited clinical trials have shown ASC feasibility and safety [74] and have revealed potential mechanisms of action of stem cell therapy in ischemic diseases, such as stroke and ischemic cardiomyopathy [74-77]. However, even with efficacy in animal studies, functional human benefits after transplantation of stem cells remain equivocal in patients with stroke [75] and heart failure $[59,60]$. Microvesicles and exosomes present a promising outlook for the treatment of ischemic diseases as well. The proangiogenic potential of ASC-released microvesicles has been shown and linked to associated micro-RNA-31 in the microvesicles [78].

By classification, stem cells undergo a finite period of multiplication as progenitor cells before completing differentiation into functional cell types [79]. Along the pathway to final differentiation, progenitor cells elicit and respond to cytokine signals that encourage cell migration and extracellular matrix invasion. Such responses have been shown in vitro for endo- 
thelial progenitor cells [80]. Relatedly, research for therapeutic angiogenesis has largely focused on the use of progenitor endothelial stem cells $[81,82]$.

Through in vivo cellular plasticity, progenitor cells, which have started down a differentiation developmental pathway, may be able to reverse the pathway back to its native state, or possibly to another differentiation lineage [83]. As such, depending on epigenetic cues, it may be possible for a differentiating osteoblastic progenitor cell to de-differentiate to a basal stem state, then down an endothelial lineage. Osteoblastic progenitor cells, as they are heavily involved in VEGF stimulated responses in embryonic and adult perichondrial angiogenesis and bone formation may be a logical VEGF vehicle for the treatment of ischemic disease. Their benefit may lie in the possible sustained paracrine elaboration of VEGF after engraftment, as well as possible dedifferentiation to cardiomyocyte lineage and/ or endothelial lineage. Additionally, progenitor cell homing, whereby the cells are attracted to the chemoattractant gradient in response to ischemic tissue injury, occurs in all tissues for the replacement of cells [84-86]. Peripherally infused osteogenic progenitor cells may be able to home to the affected ischemic tissue for therapy. As such, the progenitor cell may hold several tools in its therapeutic toolbox, beyond our traditional understanding of multi-differentiation and cytokine elaboration.

\section{Conclusions}

VEGF remains a critical constituent for angiogenesis and organ development. Similarly, VEGF therapy alone has shown encouraging trends in the clinical treatment of ischemic disease. Modulating VEGF delivery with regenerative cellbased vehicles, such as with osteogenic progenitor cells, may improve clinical efficacy in the treatment of ischemic disease.

\section{References}

1. World Health Organization. Cardiovascular diseases, fact sheet 2017.

2. (2018) National Heart, Lung, and Blood Institute. Coronary heart disease.

3. Lloyd-Jones DM, Hong Y, Labarthe D, et al. (2010) Defining and setting national goals for cardiovascular health promotion and disease reduction: The American heart association's strategic impact goal through 2020 and beyond. Circulation 121:586613.

4. Benjamin EJ, Virani SS, Callaway CW, et al. (2018) Heart disease and stroke statistics-2018 update: A report from the American heart association. Circulation.

5. Hunter J. A (2007) treatise on the blood, inflammation, and gun-shot wounds. 1794 Clin Orthop Relat Res. 458:27-34.

6. Folkman J (1971) Tumor angiogenesis: Therapeutic implications. N Engl J Med 285:1182-1186.

7. Murray JD, Carlson GW, McLaughlin K, et al. (1997) Tumor angiogenesis as a prognostic factor in laryngeal cancer. Am J Surg 174:523-526.

8. Senger DR, Galli SJ, Dvorak AM, Perruzzi CA (1983) Tumor cells secrete a vascular permeability factor that promotes the accumulation of ascites fluid. Science 219:983-985.

9. Ferrara N, Henzel WJ (1989) Pituitary follicular cells secrete a novel heparin-binding growth factor specific for vascular endothelial cells. BiochemBiophys Res Commun 161:851-858.

10. Ferrara N, Hillan KJ, Gerber HP, Novotny W (2004) Discovery and development of bevacizumab, an anti-VEGF antibody for treating cancer. Nat Rev Drug Discov 3:391-400.

11. Taimeh Z, Loughran J, Birks EJ, Bolli R (2013) Vascular endothelial growth factor in heart failure. Nat Rev Cardiol 10:519-530.

12. Ucuzian AA, Gassman AA, East AT, Greisler HP (2010) Molecular mediators of angiogenesis. J Burn Care Res. 31:158175.

13. Fearnley GW, Smith GA, Harrison MA, et al. (2013) Vascular endothelial growth factor-A regulation of blood vessel sprouting in health and disease. OA Biochemistry 1.

14. Fearnley GW, Smith GA, Abdul-Zani I, et al. (2016) VEGFA isoforms program differential VEGFR2 signal transduction, trafficking, and proteolysis. Biol Open 5:571-583.

15. Smith GA, Fearnley GW, Harrison MA, Tomlinson DC, (2015) Vascular endothelial growth factors: Multitasking functionality in metabolism, health, and disease. J Inherit Metab Dis. 38:753-763. 
16. Harper SJ, Bates DO (2008) VEGF-A splicing: The key to anti-angiogenic therapeutics? Nat Rev Cancer. 8:880-887.

17. Karki S, Ngo DTM, Farb MG, et al. (2017) WNT5A regulates adipose tissue angiogenesis via anti angiogenic VEGFA165b in obese humans. Am J Physiol Heart Circ Physiol. 313: H200-H206.

18. Kikuchi R, Nakamura K, MacLauchlan S, et al. (2014) An anti angiogenic isoform of VEGF-A contributes to impaired vascularization in peripheral artery disease. Nat Med 20:14641471.

19. Eswarappa SM, Potdar AA, Koch WJ, et al. (2014) Programmed translational read-through generates anti angiogenic VEGF-ax. Cell 157:1605-1618.

20. Atluri P, Woo YJ (2008) Pro-angiogenic cytokines as cardiovascular therapeutics: Assessing the potential. Bio Drugs. 22:209-222.

21. Eppler SM, Combs DL, Henry TD, et al. (2002) A targetmediated model to describe the pharmacokinetics and hemodynamic effects of recombinant human vascular endothelial growth factor in humans. Clin Pharmacol Ther. 72:20-32.

22. Sato K, Wu T, Laham RJ, et al. (2001) Efficacy of intracoronary or intravenous VEGF165 in a pig model of chronic myocardial ischemia. J Am Coll Cardiol 37:616-623.

23. Henry TD, Annex BH, McKendall GR, et al. (2003) The VIVA trial: Vascular endothelial growth factor in ischemia for vascular angiogenesis. Circulation 107:1359-1365.

24. Gyongyosi M, Khorsand A, Zamani S, et al. (2005) NOGAguided analysis of regional myocardial perfusion abnormalities treated with intramyocardial injections of plasmid encoding vascular endothelial growth factor A-165 in patients with chronic myocardial ischemia: Sub analysis of the EUROINJECT-ONE multicenter double-blind randomized study. Circulation 112:I157-1165.

25. Stewart DJ, Kutryk MJ, Fitchett D, et al. (2009) VEGF gene therapy fails to improve perfusion of ischemic myocardium in patients with advanced coronary disease: Results of the NORTHERN trial. MolTher 17:1109-1115.

26. Hedman M, Hartikainen J, Syvanne M, et al. (2003) Safety and feasibility of catheter-based local intracoronary vascular endothelial growth factor gene transfer in the prevention of post angioplasty and in-stent restenosis and in the treatment of chronic myocardial ischemia: Phase II results of the Kuopio angiogenesis trial (KAT). Circulation. 107:2677-2683. .

27. Kastrup J, Jorgensen E, Fuchs S, et al. (2011) A randomized, double-blind, placebo-controlled, multicentre study of the safety and efficacy of BIOBYPASS (AdGVVEGF121.10NH) gene therapy in patients with refractory advanced coronary artery disease: The NOVA trial. EuroIntervention 6:813-818.
28. Cleland JL, Duenas ET, Park A, et al. (2001) Development of poly-(D, L-lactide-coglycolide) microsphere formulations containing recombinant human vascular endothelial growth factor to promote local angiogenesis. J Control Release. 72:13-24.

29. Simon-Yarza T, Formiga FR, Tamayo E, et al.(2012) Vascular endothelial growth factor-delivery systems for cardiac repair: An overview. Theranostics 2:541-552.

30. Prestwich GD, Erickson IE, Zarembinski TI, et al. (2012) The translational imperative: Making cell therapy simple and effective. Acta Biomater 8:4200-4207.

31. Grdisa M (2011) The delivery of biologically active (therapeutic) peptides and proteins into cells. Curr Med Chem 18:1373-1379.

32. Bender E (2016) Cell-based therapy: Cells on trial. Nature 540:106-108.

33. Buzhor E, Leshansky L, Blumenthal J, et al. (2014) Cellbased therapy approaches The hope for incurable diseases. Regen Med 9:649-672.

34. Kalladka D, Sinden J, Pollock K, et al. (2016) Human neural stem cells in patients with chronic ischaemic stroke (PISCES): A phase 1, first-in-man study. Lancet 388:787-796.

35. Schaun MI, Eibel B, Kristocheck M, et al. (2016) Cell therapy in ischemic heart disease: Interventions that modulate cardiac regeneration. Stem Cells Int.

36. Liebson PR (2015) Stem-cell angiogenesis and regeneration of the heart: Review of a saga of 2 decades. Clin Cardiol. 38:309-316.

37. Payne TR, Oshima H, Okada M, et al. (2007) A relationship between vascular endothelial growth factor, angiogenesis, and cardiac repair after muscle stem cell transplantation into ischemic hearts. J Am Coll Cardiol 50:1677-1684.

38. Matsumoto R, Omura T, Yoshiyama M, et al. (2005) Vascular endothelial growth factor-expressing mesenchymal stem cell transplantation for the treatment of acute myocardial infarction. Arterioscler Thromb Vasc Biol. 25:1168-1173.

39. Borlongan CV (2016) Age of PISCES: Stem-cell clinical trials in stroke. Lancet 388:736-738.

40. Hou L, Kim JJ, Woo YJ, Huang NF (2016) Stem cell-based therapies to promote angiogenesis in ischemic cardiovascular disease. Am J Physiol Heart Circ Physiol. 310:455-465.

41. Mackie AR, Losordo DW (2011) CD 34-positive stem cells: In the treatment of heart and vascular disease in human beings. Tex Heart Inst J 38:474-485.

42. Sukmawati D, Tanaka R (2015) Introduction to the next generation of endothelial progenitor cell therapy: A promise in vascular medicine. Am J Transl Res 7:411-421. 
43. Halvorsen YC, Wilkison WO, Gimble JM (2000) Adiposederived stromal cells--their utility and potential in bone formation. Int J ObesRelat Metab Disord 24 Suppl 4: S41-44.

44. Kapur SK, Dos-AnjosVilaboa S, Llull R, Katz AJ (2015)Adipose tissue and stem/progenitor cells: Discovery and development. Clin Plast Surg. 42:155-167.

45. Brown SA, Levi B, Lequeux C, Wong VW, Mojallal A, (2010) Basic science review on adipose tissue for clinicians. Plast Reconstr Surg.126:1936-1946.

46. De Francesco F, Ricci G, D'Andrea F,et al. (2015) Human adipose stem cells: From bench to bedside. Tissue Eng Part B Rev 21:572-584.

47. Zuk PA, Zhu M, Mizuno H, et al. (2001) Multilineage cells from human adipose tissue: Implications for cell-based therapies. Tissue Eng 7:211-228.

48. Zuk PA, Zhu M, Ashjian P, et al. (2002) Human adipose tissue is a source of multipotent stem cells. MolBiol Cell 13:42794295.

49. Strem BM, Hicok KC, Zhu M, et al.(2005) Multipotential differentiation of adipose tissue-derived stem cells. Keio J Med 54:132-141.

50. Lavoie JR, Rosu-Myles M (2013) Uncovering the secrets of mesenchymal stem cells. Biochimie 95:2212-2221.

51. Brown JC, Shang H, Li Y, et al. (2017) Isolation of adiposederived stromal vascular fraction cells using a novel point-ofcare device: Cell characterization and review of the literature. Tissue Eng Part C Methods 23:125-135.

52. Zuk PA, Zhu M, Ashjian P, et al. (2002) Human adipose tissue is a source of multipotent stem cells. MolBiol Cell 13:42794295.

53. Kilroy GE, Foster SJ, Wu X, et al. (2007) Cytokine profile of human adipose-derived stem cells: Expression of angiogenic, hematopoietic, and pro-inflammatory factors. J Cell Physiol 212:702-709.

54. Planat-Benard V, Menard C, Andre M, et al. (2004) Spontaneous cardiomyocyte differentiation from adipose tissue stroma cells. Circ Res 94:223-229.

55. Strem BM, Zhu M, Alfonso Z, et al. (2005) Expression of cardiomyocytic markers on adipose tissue-derived cells in a murine model of acute myocardial injury. Cytotherapy 7:282291.

56. Fraser JK, Schreiber R, Strem B, et al. (2006) Plasticity of human adipose stem cells toward endothelial cells and cardiomyocytes. Nat Clin Pract Cardiovasc Med 3Suppl 1: S33-37.
57. Ankrum JA, Ong JF, Karp JM (2014) Mesenchymal stem cells: Immune evasive, not immune privileged. Nat Biotechnol 32:252-260.

58. Zhao L, Johnson T, Liu D (2017) Therapeutic angiogenesis of adipose-derived stem cells for ischemic diseases. Stem Cell Res Ther 8:125.

59. Sussman MA, Murry CE (2008) Bones of contention: Marrow-derived cells in myocardial regeneration. J Mol Cell Cardiol 44:950-953.

60. Thakker R, Yang P (2014) Mesenchymal stem cell therapy for cardiac repair. Curr Treat Options Cardiovasc Med 16:323.

61. Rehman J, Traktuev D, Li J, et al. (2004) Secretion of angiogenic and antiapoptotic factors by human adipose stromal cells. Circulation 109:1292-1298.

62. Kapur SK, Katz AJ (2013) Review of the adipose-derived stem cell secretome. Biochimie 95:2222-2228.

63. Gnecchi M, He H, Noiseux N, et al. (2006) Evidence supporting the paracrine hypothesis for Akt-modified mesenchymal stem cell-mediated cardiac protection and functional improvement. FASEB J 20:661-669.

64. Kinnaird T, Stabile E, Burnett MS, et al. (2004) Marrow-derived stromal cells express genes encoding a broad spectrum of arteriogenic cytokines and promote in vitro and in vivo arteriogenesis through paracrine mechanisms. Circ Res 94:678-685.

65. Crivellato $\mathrm{E}$ (2011) The role of angiogenic growth factors in organogenesis. Int J Dev Biol 55:365-375.

66. Risau W (1998) Development and differentiation of endothelium. Kidney Int Suppl 67: S3-6.

67. Ribatti D (2006) Genetic and epigenetic mechanisms in the early development of the vascular system. J Anat. 208:139-152.

68. Slack J (2018) Organogenesis. In: The science of stem cells. 2018th ed. Hoboken, NJ: Wiley Blackwell 144-145.

69. Cleaver O, Melton DA (2003) Endothelial signaling during development. Nat Med 9:661-668.

70. Duan X, Murata Y, Liu Y, Nicolae C (2015) Vegfa regulates perichondrial vascularity and osteoblast differentiation in bone development. Development 142 :1984-1991.

71. Street J, Lenehan B (2009) Vascular endothelial growth factor regulates osteoblast survival - evidence for an autocrine feedback mechanism. J Orthop Surg Res 4:19. 
72. Berendsen AD, Olsen BR (2014) How vascular endothelial growth factor-A (VEGF) regulates differentiation of mesenchymal stem cells. J Histochem Cytochem 62:103-108.

73. Nakagami H, Maeda K, Morishita R, et al. (2005) Novel autologous cell therapy in ischemic limb disease through growth factor secretion by cultured adipose tissue-derived stromal cells. Arterioscler Thromb Vasc Biol. 25:2542-2547.

74. Perin EC, Sanz-Ruiz R, Sanchez PL, et al. (2014) Adiposederived regenerative cells in patients with ischemic cardiomyopathy: The PRECISE trial. Am Heart J 168:88-95.

75. Prasad K, Sharma A, Garg A, et al. (2014) Intravenous autologous bone marrow mononuclear stem cell therapy for ischemic stroke: A multicentric, randomized trial. Stroke. 45:3618-3624.

76. Nguyen PK, Rhee JW, Wu JC. (2016) Adult stem cell therapy and heart failure, 2000 to 2016: A systematic review. JAMA Cardiol 1:831-841.

77. Houtgraaf JH, den Dekker WK, van Dalen BM, et al. (2012) First experience in humans using adipose tissue-derived regenerative cells in the treatment of patients with ST-segment elevation myocardial infarction. J Am Coll Cardiol 59:539-540.

78. Kang T, Jones TM, Naddell C, et al. (2016) Adipose-derived stem cells induce angiogenesis via microvesicle transport of miRNA-31. Stem Cells Transl Med 5:440-450.

79. Slack J (2018) What is a stem cell? In: The science of stem cells. 2018th ed. Hoboken, NJ: Wiley Blackwell :2.

80. Kamprom W, Kheolamai P, U-Pratya Y, et al. (2016) Effects of mesenchymal stem cell-derived cytokines on the functional properties of endothelial progenitor cells. Eur J Cell Biol 95:153-163.

81. Asahara T, Murohara T, Sullivan A, et al. (1997) Isolation of putative progenitor endothelial cells for angiogenesis. Science 275:964-967.

82. Hur J, Yoon CH, Kim HS, et al. (2004) Characterization of two types of endothelial progenitor cells and their different contributions to neovasculogenesis. Arterioscler Thromb Vasc Biol 24:288-293.
83. Sanchez Alvarado A, Yamanaka S (2014) Rethinking differentiation: Stem cells, regeneration, and plasticity. Cell 157:110119.

84. Tavassoli M, Hardy CL (1990) Molecular basis of homing of intravenously transplanted stem cells to the marrow. Blood 76:1059-1070.

85. Shi M, Li J, Liao L, et al. (2007) Regulation of CXCR4 expression in human mesenchymal stem cells by cytokine treatment: Role in homing efficiency in NOD/SCID mice. Haematologica 92:897-904.

86. Kronenwett R, Martin S, Haas R (2000) The role of cytokines and adhesion molecules for mobilization of peripheral blood stem cells. Stem Cells 18:320-330.

Submit your manuscript to a JScholar journal and benefit from:

ฯ Convenient online submission

ब Rigorous peer review

I Immediate publication on acceptance

q Open access: articles freely available online

I High visibility within the field

I Better discount for your subsequent articles

Submit your manuscript at http://www.jscholaronline.org/submit-manuscript.php 